\title{
Correction to: Animals in Our Midst: The Challenges of Co-existing with Animals in the Anthropocene
}

\author{
Bernice Bovenkerk and Jozef Keulartz
}

\section{Correction to:}

B. Bovenkerk and J. Keulartz (eds.), Animals in Our Midst: The Challenges of Co-existing with Animals in the Anthropocene, The International Library of Environmental, Agricultural and Food Ethics 33, https://doi.org/10.1007/978-3-030-63523-7

The original version of this chapter was inadvertently published with incorrect author name in Chapters 1 and 3 reference citations and list. The author's name is corrected from "O'Neill, J.S. and M.H. Hastings" to "David A. Leavens". The book has been updated with the changes. 